\title{
Impacts of Animal Herbivory and Water Depth on Seed Germination and Seedling Survival of Vallisneria natans (Lour.) Hara and Hydrilla verticillata (L. f.) Royle
}

\author{
Fenli Min ${ }^{1,2}$, Jincheng Zuo³, Qingwei Lin", ${ }^{1,}$ Yi Zhang1, Biyun Liu ${ }^{1 *}$, \\ Jian Sun ${ }^{1,2}$, Feng $\mathrm{He}^{1^{*}}$, Zhenbin $\mathrm{Wu}^{1}$ \\ ${ }^{1}$ State Key Laboratory of Freshwater Ecology and Biotechnology, Institute of Hydrobiology, \\ Chinese Academy of Sciences, Wuhan, China \\ ${ }^{2}$ University of Chinese Academy of Sciences, Beijing, China \\ ${ }^{3}$ School of Life Science, Ludong University, Yantai, China
}

Received: 17 November 2017

Accepted: 21 January 2018

\begin{abstract}
Seed germination is an important reproductive pattern for submerged macrophytes. In order to investigate the effects of animal herbivory and water depth on seed germination and seedling survival of Vallisneria natans and Hydrilla verticillata, we conducted an in-situ field experiment at 3 water depths $(0.5,1$, and $2 \mathrm{~m})$ with net and non-net (control) groups in Hangzhou West Lake, China. The results showed that the highest germination rates appeared at $1 \mathrm{~m}$ water depth and the lowest germination rates appeared at $2 \mathrm{~m}$ water depth $(p<0.05)$ for both species. The mean time to germination (MTG) values that indicate the velocity of germination are greater at $2 \mathrm{~m}$ water depth than that at $0.5 \mathrm{~m}$ and $1 \mathrm{~m}$ water depths for both $V$. natans and $H$. verticillata. Net protection obviously promoted germination rates of both species at $0.5 \mathrm{~m}$ and $1 \mathrm{~m}$ depths, especially for $H$. verticillata at $1 \mathrm{~m}(p<0.05)$. Germination rates of $H$. verticillata were higher than that of $V$. natans under any treatment $(p<0.05)$. In the control, seedlings of both species were greatly grazed by herbivorous animals and the remaining seedling number showed no significant difference at different depths $(p>0.05)$. Remaining seedling number in net group was significantly higher than that in control group $(p<0.05)$. Grazing rate of $H$. verticillata was significantly higher than that of $V$. natans in control group at all 3 depths $(p<0.05)$. Conclusively, both water depth and animal herbivory significantly influenced germination of $V$. natans and $H$. verticillata, and net protection proved to be an efficient method that could promote seedling survival for both species in the field.
\end{abstract}

Keywords: Vallisneria natans, Hydrilla verticillata, seed germination, water depth, animal herbivory, seedling survival

*e-mail: liuby@ihb.ac.cn, hefeng@ihb.ac.cn 


\section{Introduction}

Submerged macrophytes play a crucial role in shallow lake ecosystems by sequestering carbon and nutrients, providing habitats for a variety of aquatic faunal communities, and stabilizing sediments and shorelines [1-3]. Restoring submerged macrophytes can improve the ecological condition in eutrophic lakes, making a shift from a turbid water state to a clear one [4-5]. In natural conditions, most aquatic plants give priority to clonal reproduction [6-7], and seed germination is not a dominating but still indispensable pattern for reproducing submerged macrophytes [8-9].

Although seed germination of terrestrial species has been extensively studied, seed germination of submerged macrophytes is still rarely concerned [10-12]. In fact, seeds of submerged macrophytes have been found to play important roles in the formation of new gene and genotypes in the present populations [13], re-establishing populations after abrupt recession [12, 14], and long-distance dispersal and long-term dormancy of populations [15-16]. For now, submerged macrophyte restoration efforts mainly used adult plants introduced from other well-grown populations [5, 17], which may bring some human-induced destruction to source populations. Moreover, the survival ratio of transplanted submerged macrophyte cannot be guaranteed and dead plants would bring extra pollution to eutrophic lakes. Furthermore, such manual transplantation is timeconsuming and laborious. However, seed restoration is more straightforward, economical, and environmentfriendly, thus it seems to be a potential alternative choice for restoring submerged macrophytes in eutrophic lakes.

In natural conditions, seeds of submerged macrophytes are sensitive to ambient environments. Seed germination and seedling survival rate can be affected by many environmental factors such as temperature, light, salinity, oxygen, and sediment composition [12, 18-19]. Water depth is a practical factor in nature, which greatly affects the distribution and growth of submerged macrophytes in conjunction with other factors such as light, waves, and water flow [20-22]. Cao et al. (2014) found that water depth influenced biomass and chlorophyll content of Vallisneria natans, and that 1-1.4 m water depth was favorable for plants [23]. A similar result showed that 1.1-1.6 m water depths were optimal for clonal growth of $V$. natans [24]. However, few studies have investigated the effects of water depth on seed germination of submerged macrophytes in the field.

It is clear that submerged macrophytes can be grazed by a variety of animals, such as herbivorous fish, waterfowl, and snails [25-27]. Herbivory is considered to be an important factor for structuring aquatic macrophyte communities [25]. Herbivorous fish, such as grass carp, have been used as a tool for weed control in the past around the world [28], and they could efficiently reduce and even eradicate entire macrophyte communities [29-30]. However, large amounts of herbivorous animals are unwelcome during the vegetation restoration period due to their great destructive impacts. Krupska et al. (2012) suggested that grass carp in shallow lakes would lead to a reduction of biomass and diversity of submerged macrophytes, as well as the reduction of water transparency [31]. Therefore, it is important to evaluate the effect of herbivorous animals before restoring submerged macrophytes in a degraded lake. Enclosures with net were always used to provide a safe and stable environment for the recovery of submerged vegetation [32-33].

In this study, in order to investigate the potential of seed restoration in eutrophic lakes, we have considered the effects of water depth and animal herbivory on seed germination and seedling early growth of Vallisneria natans (Lour.) Hara and Hydrilla verticillata (L. f.) Royle in a field in-situ experiment. $V$. natans and $H$. verticillata are both common dominant species in the middle and lower reaches of the Yangtze River and are always used as pioneer species for ecological restoration due to their strong tolerance to pollution, high reproducibility, and strong adaptability to the environment. We have set 2 protection treatments (net group and control group, or non-net group) and 3 water depths $(0.5,1.0$, and $2.0 \mathrm{~m})$ for seed germination of both plants. Seed germination rates, velocities, and remaining seedlings (after disturbance by herbivorous animals) have been counted for analyzing the differences among treatments.

\section{Materials and Methods}

\section{Study Site}

The in-situ experiment was carried out in Xiaonanhu Lake (N 30 $13^{\prime} 5^{\prime \prime}$, E $120^{\circ} 8^{\prime} 27^{\prime \prime}$ ), a sub-lake of Hangzhou West Lake in China, which is a world-famous landscape
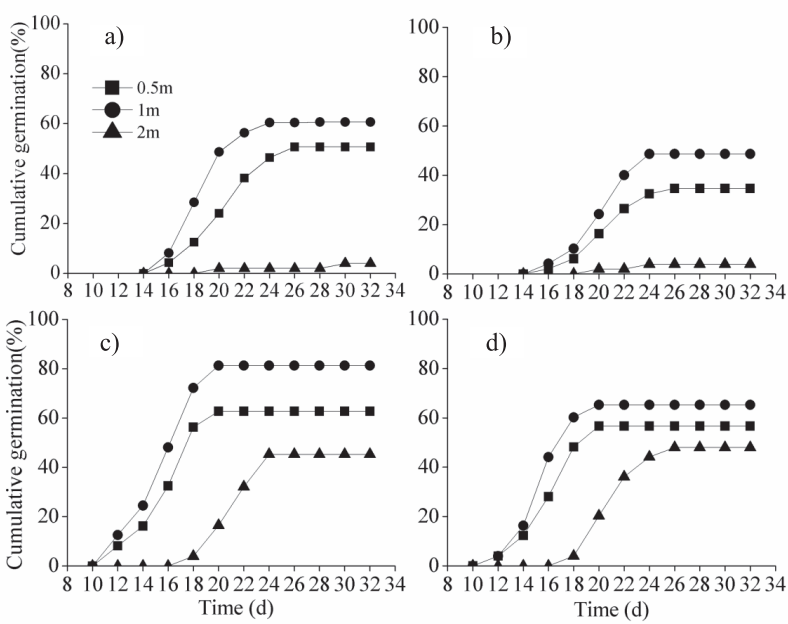

Fig. 1. Cumulative germination of $V$. natans and $H$. verticillata (means \pm S.E., $n=3$ ) under different treatments: a), b), c), and d) respectively represent $V$. natans in net group, $V$. natans in control group, $H$. verticillata in net group, and $H$. verticillata in control group. 
Table 1. Water and sediment parameters (means \pm S.E., $\mathrm{n}=3$ ) in Xiaonanhu Lake during the experimental period.

\begin{tabular}{|c|c|c|c|}
\hline \multicolumn{2}{|c|}{ Water parameters } & \multicolumn{2}{c|}{ Sediment parameters } \\
\hline $\mathrm{TN}(\mathrm{mg} / \mathrm{L})$ & $2.2 \pm 0.12$ & $\mathrm{TN}(\mathrm{mg} / \mathrm{g})$ & $6.62 \pm 0.33$ \\
\hline $\mathrm{AN}(\mathrm{mg} / \mathrm{L})$ & $0.032 \pm 0.006$ & $\mathrm{TP}(\mathrm{mg} / \mathrm{g})$ & $6.21 \pm 0.09$ \\
\hline Nitrate-N (mg/L) & $2.12 \pm 0.12$ & $\mathrm{pH}$ & $123.4 \pm 6.63$ \\
\hline Nitrite-N (mg/L) & $0.044 \pm 0.006$ & $\mathrm{ORP}(\mathrm{mv})$ & $4.32 \pm 0.19$ \\
\hline $\mathrm{TP}(\mathrm{mg} / \mathrm{L})$ & $0.015 \pm 0.003$ & & \\
\hline $\mathrm{Chl}-\mathrm{a}(\mathrm{mg} / \mathrm{L})$ & $4.55 \pm 0.23$ & & \\
\hline $\mathrm{COD}$ & $28.23 \pm 3.6$ & & \\
\hline $\mathrm{SD}(\mathrm{m})$ & $1.5 \pm 0.23$ & & \\
\hline
\end{tabular}

TN: total nitrogen, AN: ammonia nitrogen, TP: total phosphorus, SD: Secchi depth, ORP: oxidation-reduction potential, OSC: organic substances content

freshwater lake with a water surface area of $6.39 \mathrm{~km}^{2}$ and had been included in the world heritage list in 2011 . Since 2003 the government has made a lot of efforts to improve water quality and build a healthy aquatic ecosystem in West Lake, such as ecological water diversion, dredging, and a fishing ban. Meanwhile, after implementing the national water project in the $12^{\text {th }}$ five-year plan, submerged macrophytes - as an important part of a healthy ecosystem - have been restored in several sub-lakes of West Lake, including Xiaonanhu Lake. The submerged vegetation was restored with adult plants and mainly distributed in the littoral zone, where water depth is comparatively shallow. Seed restoration of $V$. natans has been tried but failed for unknown reasons. According to a 3-month investigation, large amounts of fish and snails exist in Xiaonanhu Lake. Herbivorous and omnivorous fish like grass carp, crucian carp, and common carp accounted for $79.1 \%$ of the fish, which may threaten the growth of submerged macrophytes, especially the tender seedlings. The experiment was carried out in the northern part of Xiaonanhu Lake as shown in Fig. 1, where the water depth was about $2.4 \mathrm{~m}$. The water and sediment parameters of the study site are shown in Table 1.

\section{Materials and Pretreatment}

In this study, seed pods of $V$. natans were collected in October 2015 and reproductive spores of $H$. verticillata were collected in September 2015 (both from the West Lake), wind dried in natural conditions, and reserved under $4^{\circ} \mathrm{C}$ for subsequent use. Before the experiment, dry seed pods of $V$. natans were put into tap water for 8 hours, then seed pods were washed 2-3 times with tap water a nd seeds were kneaded out from their seed coats. Seeds of $V$. natans and spores of $H$. verticillata were both kept in $4 \%$ formalin disinfection solution for $60 \mathrm{~min}$ and then rinsed with clean water. Sediments less than $15 \mathrm{~cm}$ depth of the top surface layer were collected at the study site and the corresponding parameters are shown in Table 1. In order to remove impurities (benthonic faunas and others) and avoid disturbance of the seed bank, sediments were wet-sieved through a $2 \mathrm{~mm}$ sieve and mixed thoroughly to evenly distribute the physical and chemical properties. Little plastic buckets (upper diameter $20 \mathrm{~cm}$, lower diameter $15 \mathrm{~cm}$, height $15 \mathrm{~cm}$ ), a nylon net of $1 \mathrm{~cm}$ pore size, tenuous nylon rope, and an elastic band were also used in this field experiment.

\section{Seed Bank Analysis}

Prior to the germination experiment, 3 sediment cores (depth $25 \mathrm{~cm}$ ) were taken from Xiaonanhu Lake at 3 randomly designed sampling sites where water depth is more than $1.5 \mathrm{~m}$ and a few submerged plants existed. The sediment cores were divided into several slices for isolation, identification, and germination trials according to Rodrigo et al. (2010) [34]. Nearly no obvious seed or propagule has been found and no germination has been observed from the sediment.

\section{Experimental Setup}

The experiment was based on a $2 \times 3$ factorial design with 2 groups (net group and control group, or non-net group) and 3 water depth gradients $(0.5 \mathrm{~m}, 1.0 \mathrm{~m}$, and $2.0 \mathrm{~m}$ ) in Xiaonanhu Lake in-situ. Each treatment was conducted with 3 replicates. Each plastic bucket filled with $5 \mathrm{~cm}$ thick of homogeneous sediment was evenly planted with 25 spores of $H$. verticillata (or 50 seeds of $V$. natans) on the sediment surface. In the net group, the upper side of the bucket was covered with nylon net affixed using an elastic band. All the buckets were put into designed water depth using tenuous nylon rope and fixed to stakes nailed in Xiaonanhu Lake in advance. Germination was monitored by boat until no more new buds were observed for 5 consecutive days.

All the buckets were labeled and checked every 2 days. The number of germinated seeds and spores in each bucket were counted. The seeds and spores were considered as germinated when the bud emerged from the seed coat. In the control group, seedlings less than 
Table 2. Final germination and MTG values of $V$. natans and H. verticillata.

\begin{tabular}{|c|c|c|c|c|c|c|}
\hline & \multicolumn{3}{|c|}{ Final germination (\%) } & & \multicolumn{3}{c|}{ MTG (d) } \\
\hline Treatment & V.natans & H. verticillata & F-value & V. natans & H. verticillata & F-value \\
\hline $0.5 \mathrm{~m}$ net & $50.7 \pm 4.9^{\mathrm{ab}}$ & $62.7 \pm 2.4^{\mathrm{b}}$ & $6.9^{*}$ & $21.0 \pm 0.6^{\mathrm{b}}$ & $16.5 \pm 0.9^{\mathrm{b}}$ & $18.7^{*}$ \\
\hline $0.5 \mathrm{~m}$ control & $34.7 \pm 2.4^{\mathrm{b}}$ & $56.7 \pm 3.7^{\mathrm{bc}}$ & $23.6^{* *}$ & $21.2 \pm 0.7^{\mathrm{b}}$ & $16.7 \pm 1.0^{\mathrm{b}}$ & $14^{*}$ \\
\hline $1 \mathrm{~m}$ net & $60.7 \pm 5.2^{\mathrm{a}}$ & $81.3 \pm 3.1^{\mathrm{a}}$ & $11.4^{*}$ & $19.3 \pm 0.5^{\mathrm{b}}$ & $15.9 \pm 1.1^{\mathrm{b}}$ & $8.2^{*}$ \\
\hline $1 \mathrm{~m}$ control & $48.7 \pm 4.9^{\mathrm{ab}}$ & $65.3 \pm 3.5^{\mathrm{b}}$ & $6.8^{*}$ & $20.8 \pm 1.0^{\mathrm{b}}$ & $16.1 \pm 0.6^{\mathrm{b}}$ & $14.9^{*}$ \\
\hline $2 \mathrm{~m}$ net & $4.0 \pm 1.5^{\mathrm{c}}$ & $45.3 \pm 2.6^{\mathrm{c}}$ & $165.1^{* * *}$ & $25.0 \pm 0.7^{\mathrm{a}}$ & $21.8 \pm 1.0^{\mathrm{a}}$ & 6.6 \\
\hline $2 \mathrm{~m}$ control & $4.0 \pm 0.6^{\mathrm{c}}$ & $48.0 \pm 3.6^{\mathrm{c}}$ & $122.5^{* * *}$ & $22.0 \pm 0.5^{\mathrm{ab}}$ & $21.7 \pm 1.0^{\mathrm{ab}}$ & 0.08 \\
\hline
\end{tabular}

Values in the table are means \pm S.E., $n=3$; different letters indicate that means are significantly different in the columns (Tukey's test, $p<0.05$ ); $F$ values of one-way analysis of variance between $V$. natans and $H$. verticillata are shown in the table; ${ }^{*} p<0.05 .{ }^{* *} p<0.01 .{ }^{* * *} p<0.001$

$2 \mathrm{~cm}$ after grazing by animals were considered to have been eaten, and the remaining seedlings in each bucket were counted. The velocity of germination was calculated using the MTG index:

$$
\mathrm{MTG}=\sum\left(\mathrm{n}_{\mathrm{i}} \times \mathrm{d}_{\mathrm{i}}\right) / \mathrm{N}
$$

...where $n_{i}$ is the number of seeds germinated at day $i, d_{i}$ is the incubation period in days, and $\mathrm{N}$ is the total number of seeds germinating in the treatment [35]. Grazing rate was defined as the ratio between the number of eaten seedlings and the number of germinated seedlings in each bucket. The experiment was started on 15 April and seed germination and seedling survival situation was monitored for 50 days.

\section{Data Analysis}

All data in the figures and tables were presented as means \pm S.E. and were arcsine transformed before statistical analysis to ensure homogeneity of variance. Effects of water depth and net protection on germination and seedling survival of the two species were analyzed using one- and two-way analysis of variance with SPSS for windows, version 21.0. Post-hoc comparisons for all analyses were made with Tukey's HSD test.

\section{Results}

\section{Effects on Final Germination}

Net protection and water depth both significantly $(p<0.05)$ influenced the final germination of $V$. natans and $H$. verticillata, and their interaction significantly $(p<0.05)$ influenced the final germination of $H$. verticillata. The specific order of water depth in favor of seed germination of both species was $1 \mathrm{~m}>0.5 \mathrm{~m}>$ $2 \mathrm{~m}$. The final germination rates in the net group were higher than in the control group at $0.5 \mathrm{~m}$ and $1 \mathrm{~m}$ water depths. For $V$. natans, germination rates were significantly lower at $2 \mathrm{~m}$ water depth in both net and control groups. For $H$. verticillata, germination rates were significantly higher in the net group than that in the control group at $1 \mathrm{~m}$ water depth $(p<0.05)$, and germination rates were significantly lower at $2 \mathrm{~m}$ water depth than at other water depths $(p<0.05)$. Final germination rates of $H$. verticillata were significantly higher than that of $V$. natans under all treatments $(p<0.05$; Table 2$)$.

\section{Effects on Velocity of Germination}

Seeds of $V$. natans started to germinate after cultivating for 14-18 days, and spores of $H$. verticillata started to germinate after cultivating for 10-16 days (Fig. 3). Both $V$. natans and $H$. verticillata showed a later initiating time at $2 \mathrm{~m}$ water depth than that at $0.5 \mathrm{~m}$ and $1 \mathrm{~m}$ water depths (Fig. 1). Under $2 \mathrm{~m}$ water depth in the net group, the MTG values were significantly bigger than other treatments for both species $(p<0.05)$. The MTG values of $H$. verticillata were systematically lower than that of $V$. natans at both $0.5 \mathrm{~m}$ and $1 \mathrm{~m}$ depths $(p<0.05)$, while no significant differences had been found at $2 \mathrm{~m}$ water depth (Table 2).

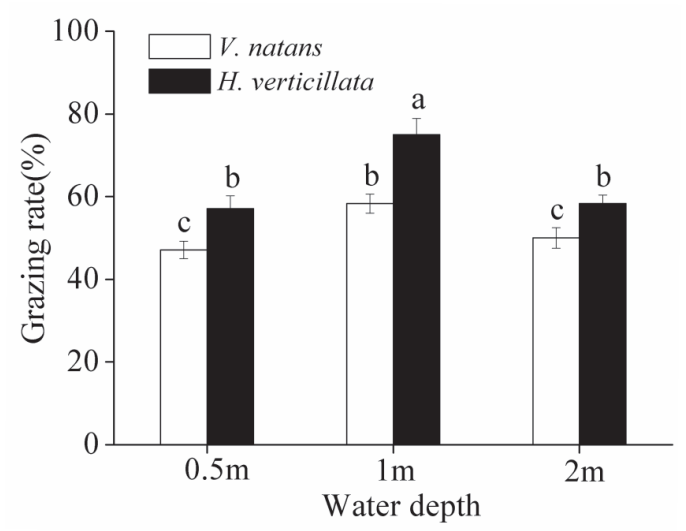

Fig. 2. Final grazing rate of $V$. natans and $H$. verticillata (means \pm S.E., $n=3$ ) in control group; different letters indicate significant differences between treatments $(p<0.05)$. 


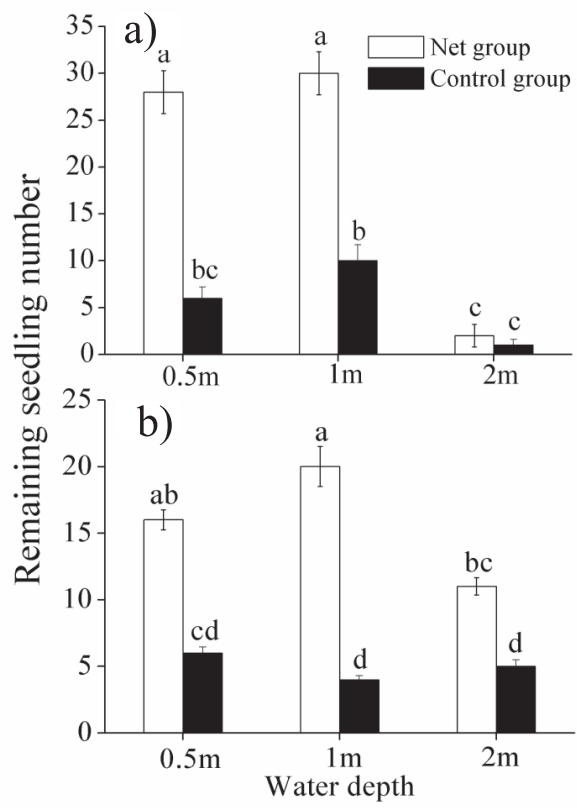

Fig. 3. Remaining seedling number of $V$. natans a) and $H$. verticillata b) (means \pm S.E., $\mathrm{n}=3$ ) in net group and control group at 3 different water depths; bars with different letters indicate significant differences between columns $(p<0.05)$.

\section{Effects on Seedling Survival}

Seedlings of $V$. natans and $H$. verticillata in control group were eaten or destroyed by herbivorous animals in the whole germination process. At the end of the experiment, in the control group, grazing rate of $V$. natans at $1 \mathrm{~m}$ water depth was significantly higher than that at $0.5 \mathrm{~m}$ and $2 \mathrm{~m}$ water depths, as was $H$. verticillata. And grazing rate of $H$. verticillata was systematically higher than that of $V$. natans at all 3 water depths (Fig. 2). Net protection seemed to be an efficient way to maintain seedling survival as the number of remaining seedlings of both species in the net group were significantly higher than that in control group $(p<0.05)$, except for the remaining seedling number of $V$. natans at $2 \mathrm{~m}$ water depth. Remaining seedling numbers of $H$. verticillata in control group showed no significant differences among different water depths ( $p>0.05$; Fig. 3).

\section{Discussion}

Growth and distribution of submerged macrophytes was affected by many factors, such as nutrients, substrate type, water movements, light, temperature, grazing pressure, and epiphyte loading. In many shallow lakes, such as Taihu, Donghu, and Hangzhou West, distribution of submerged macrophytes was prominently restricted by water level, which was supposed to be mainly related to light attenuation in the water column [36-37], although other factors such as temperature and hydrostatic pressure can also have great influence $[19,38]$. Previous studies about the effects of water level on seed germination of submerged macrophytes were mainly conducted in the laboratory, and the mechanisms of seed germination at different water depths in the field are not yet well understood. In this field study, we found that $1 \mathrm{~m}$ water depth was more favorable for seed germination of $V$. natans and $H$. verticillata compared to $0.5 \mathrm{~m}$ and $2 \mathrm{~m}$ depths. Both species showed lower germination rates at $2 \mathrm{~m}$, especially $V$. natans. Some researchers found that $V$. natans had a lower light compensation point compared to $H$. verticillata and preferred to live in a weak lighting environment [39-40]. But this may be just suitable for mature plants, not seed germination and growth of the budding seedlings. There are also researchers who argue that aquatic species that produce minute seeds require more light for seed germination in general [41-42]. So, light deficiency may be the reason for lower germination rates at $2 \mathrm{~m}$ water depth for $V$. natans, although few studies have focused on the effects of oxygen availability on seed germination. Ke and $\mathrm{Li}$ (2006) found that anaerobic conditions could accelerate seed germination of $V$. natans [11]. Similar results have been reported for Zostera marina and Zostera capricorni [43-44]. Waves on the lake's surface also could create disturbances on seed germination and the establishment of seedlings [21]. At $1 \mathrm{~m}$ water depth, dissolved oxygen content in water is lower than that at $0.5 \mathrm{~m}$ water depth, and disturbances by waves are smaller, which may be the reason for greater germination rates at $1 \mathrm{~m}$ water depth for both species. The MTG values of both species at $2 \mathrm{~m}$ water depth were greater, indicating that seed germination was delayed due to unfavorable environments at deeper water depths [45].

Although seed germination and seedling survival of terrestrial plants were greatly influenced by herbivory among terrestrial species [46-47], little is known about the effects of animal herbivory on seed germination of submerged macrophytes. In this study, a net was used to provide protection for seed germination and seedling survival of $V$. natans and $H$. verticillata in the lake. Net protection significantly affected final germination rates of both species $(p<0.05)$. Compared with the control group, germination rates of the net group were promoted for both species at $0.5 \mathrm{~m}$ and $1 \mathrm{~m}$ water depths. Except for animal interference, net protection also decreased the effects of water flow and waves, which were proven to be of great influence on reestablishing submerged macrophytes [48-49]. According to field observations, some seedlings of both species were grazed or destroyed by fish and shrimp in the control group. Seedling grazing rates of $H$. verticillata were significantly higher than that of $V$. natans at all 3 water depths in the control group. Previous studies demonstrated that different plants have different palatabilities for herbivorous animals [50-51]. Sun et al. (2015) demonstrated that $H$. verticillata had better palatability for herbivorous animals than $V$. natans [52], which was consistent with the results of this study. Compared to the net group, significantly fewer remaining seedlings survived in the control group for both $V$. natans and $H$. verticillata, indicating that the net could efficiently protect seedlings 
of both species from herbivorous animals. Kloskowski (2011) and van der Wal et al. (2013) demonstrated that the enclosure could efficiently reduce the direct impacts of herbivorous fish on submerged macrophytes in restoration, which was consistent with the results in this study [53-54].

\section{Conclusion}

In this study, water depth and animal herbivory showed great influence on seed germination and seedling survival of $V$. natans and $H$. verticillata. Both species showed the highest germination rates at $1 \mathrm{~m}$ water depth and the lowest germination rates at $2 \mathrm{~m}$ water depth - especially that of $V$. natans. Net protection could efficiently protect seedlings from being grazed by herbivorous animals, and seedlings of $H$. verticilata have a better palatability for animals than seedlings of $V$. natans. Therefore, animal herbivory should be taken into account before trying to restore and maintain a healthy submerged vegetation community in degraded lakes.

\section{Acknowledgements}

This study was supported by the Major Science and Technology Program for Water Pollution Control and Treatment of China $12^{\text {th }}$ Five-Year Plan (No. 2012ZX07101007-005), the National Nature Science Foundation of China (No. 51709254) and the state key laboratory of Freshwater Ecology and Biotechnology (No. 2017FB05). We would like to thank Lilian Wen for a constructive review and detailed suggestions for improving this manuscript.

\section{Conflict of Interest}

The authors declare no conflict of interest.

\section{References}

1. SØNDERGAARD M., JOHANSSON L.S., LAURIDSEN T.L., JORGENSEN T.B., LIBORIUSSEN L., JEPPESEN E. Submerged macrophytes as indicators of the ecological quality of lakes. Freshwater Biol. 55 (4), 893, 2010.

2. PAN G., YANG B., WANG D., CHEN H., TIAN B.H., ZHANG M.L., YUAN X.Z., CHEN J.A. In-lake algal bloom removal and submerged vegetation restoration using modified local soils. Ecol. Eng. 37 (2), 302, 2011.

3. CARR J., D'ODORICO P., MCGLATHERY K., WIBERG P. Stability and bistability of seagrass ecosystems in shallow coastal lagoons: Role of feedbacks with sediment resuspension and light attenuation. J. Geophys. Res. 115 (G3), 2010.

4. SAYER C.D., BURGESS A.M.Y., KARI K., DAVIDSON T.A., PEGLAR S., YANG H.D., ROSE N. Long-term dynamics of submerged macrophytes and algae in a small and shallow, eutrophic lake: implications for the stability of macrophyte-dominance. Freshwater Biol. 55 (3), 565, 2010.

5. BLINDOW I., HARGEBY A., HILT S. Facilitation of clear-water conditions in shallow lakes by macrophytes: differences between charophyte and angiosperm dominance. Hydrobiologia. 737 (1), 99, 2014.

6. RODRIGO M.A., ROJO C., ALONSO-GUILLÉN J.L., VERA P. Restoration of two small Mediterranean lagoons: the dynamics of submerged macrophytes and factors that affect the success of revegetation. Ecol. Eng. 54, 1, 2013.

7. HILT S., KÖHLER J., ADRIAN R., MONAGHAN M.T., SAYER C.D. Clear, crashing, turbid and back-long-term changes in macrophyte assemblages in a shallow lake. Freshwater Biol. 58 (10), 2027, 2013.

8. RIDDIN T., ADAMS J.B. The seed banks of two temporarily open/closed estuaries in South Africa. Aquat. Bot. 90 (4), 328, 2009.

9. MARTIN C.W., VALENTINE J.F. Sexual and asexual reproductive strategies of invasive Eurasian milfoil (Myriophyllum spicatum) in estuarine environments. Hydrobiologia. 727 (1), 177, 2014.

10. WALCK J.L., HIDAYATI S.N., DIXON K.W., THOMPOSON K., POSCHLOD P. Climate change and plant regeneration from seed. Global Change Biol. 17 (6), 2145, 2011.

11. Ke X.S., Li W. Germination requirement of Vallisneria natans seeds: implications for restoration in Chinese lakes. Hydrobiologia. 559, 357, 2006.

12. JARVIS J.C., MOORE K.A. Influence of environmental factors on Vallisneria americana seed germination. Aquat. Bot. 88, 283, 2008.

13. WEYL P.S.R., COETZEE J.A. Morphological variations in southern African populations of Myriophyllum spicatum: Phenotypic plasticity or local adaptation?. S. Afr. J. Bot. 103, 241, 2016.

14. BAKKER E.S., SARNEEL J.M., GULATI R.D., LIU Z.W., VAN DONK E. Restoring macrophyte diversity in shallow temperate lakes: biotic versus abiotic constraints. Hydrobiologia. 710 (1), 23, 2013.

15. CONNOLLY S.R., BAIRD A.H. Estimating dispersal potential for marine larvae: dynamic models applied to scleractinian corals. Ecology. 91 (12), 3572, 2010.

16. LONG R.L., GORECKI M.J., RENTON M., SCOTT J.K., COLVILLE L., GOGGIN D.E., COMMANDER L.E., WESTCOTT D.A., CHERRY H., FINCH-SAVAGE W.E. The ecophysiology of seed persistence: a mechanistic view of the journey to germination or demise. Biol. Rev. 90 (1), 31, 2015.

17. CHEN K.N., BAO C.H., ZHOU W.P. Ecological restoration in eutrophic Lake Wuli: a large enclosure experiment. Ecol. Eng. 35 (11), 1646, 2009.

18. KILIC S., KAHRAMAN A. The mitigation effects of exogenous hydrogen peroxide when alleviating seed germination and seedling growth inhibition on salinityinduced stress in Barley. Pol. J. Environ. Stud. 25 (3), 1053, 2016.

19. BORNETTE G., PUIJALON S. Response of aquatic plants to abiotic factors: a review. Aquat. Sci. 73 (1), 1, 2011.

20. NEPF H.M. Flow and transport in regions with aquatic vegetation. Annu. Rev. Fluid Mech. 44, 123, 2012.

21. VAN ZUIDAM B.G., PEETERS E.T.H.M. Wave forces limit the establishment of submerged macrophytes in large shallow lakes. Limnol. Oceanogr. 60 (5), 1536, 2015.

22. BAL K.D., BOUMA T.J., BUIS K., STRUYF E., JONAS S., BACKX H., MEIRE P. Trade-off between drag reduction and light interception of macrophytes: comparing 
five aquatic plants with contrasting morphology. Funct. Ecol. 25 (6), 1197, 2011.

23. CAO Y., ZHANG S.J., LIU Y.Y., GUO Z.C., CHEN B.X. Effects of water gradient on seedlings growth and biomass of Vallisneria natans. Ecology and Environmental Sciences. 23, 1332, 2014 [In Chinese].

24. XIAO K.Y., YU D., WU Z.H. Differential effects of water depth and sediment type on clonal growth of the submersed macrophyte Vallisneria natans. Hydrobiologia. 589, 265, 2007.

25. YU J.L., ZHEN W., GUAN B.H., ZHONG P., JEPPSEN E., LIU Z.W. Dominance of Myriophyllum spicatum in submerged macrophyte communities associated with grass carp. Knowl. Manag. Aquat. Ec. 417, 24, 2016.

26. SUN J., MA L., WANG L., HU Y., ZHANG Y., WU Z.B., HE F. Assessing the effects of grass carp excretion and herbivory of submerged macrophytes on water quality and zooplankton communities. Pol. J. Environ. Stud. 26 (4), 2017.

27. DORENBOSCH M., BAKKER E.S. Herbivory in omnivorous fishes: effect of plant secondary metabolites and prey stoichiometry. Freshwater Biol. 56 (9), 1783, 2011.

28. ZEHNSDORF A., HUSSNER A., EISMANN F., RONICKE H., MELZER A. Management options of invasive Elodea nuttallii and Elodea canadensis. Limnologica. 51, 110, 2015.

29. DIBBLE E.D., KOVALENKO K. Ecological impact of grass carp: a review of the available data. J. Aquat. Plant Manage. 47, 1, 2009.

30. PIPALOVA I. Initial impact of low stocking density of grass carp on aquatic macrophytes. Aquat. Bot. 73, 9, 2002.

31. KRUPSKA J., PEŁECHATY M., PUKACZ A., OSSOWSKI P. Effects of grass carp introduction on macrophyte communities in a shallow lake. Oceanol. Hydrobiol. St. 41, 35, 2012.

32. RODRIGO M.A., ROJO C., ALONSO-GUILLÉN J.L., VERA P. Restoration of two small Mediterranean lagoons: the dynamics of submerged macrophytes and factors that affect the success of revegetation. Ecol. Eng. 54, 1, 2013.

33. ZENG L., HE F., DAI Z.G., XU D., LIU B.Y., ZHOU Q.H., WU Z.B. Effect of submerged macrophyte restoration on improving aquatic ecosystem in a subtropical, shallow lake. Ecol. Eng. 106, 578, 2017.

34. RODRIGO M.A., ALONSO-GUILLÉN J.L., SOULIÉMÄRSCHE I. Reconstruction of theformer charophyte community out of the fructifications identified in Albuferade València lagoon sediments. Aquat. Bot. 92, 14, 2010.

35. REDONDO-GÓMEZ S., MATEOS-NARANJO E., WHARMBY C., LUQUE C.J., CASTILLO J.M., LUQUE T., MOHAMED M.F., DAVY A.J., FIGUEROA M.E. Bracteoles affect germination and seedling establishment in a Mediterranean population of Atriplex portulacoides. Aquat. Bot. 86, 93, 2007.

36. SCHELSKE C.L., LOWE E.F., KENNEY W.F., BATTOE L.E., BRENNER M., COVENEY M.F. How anthropogenic darkening of Lake Apopka induced benthic light limitation and forced the shift from macrophyte to phytoplankton dominance. Limnol. Oceanogr. 55 (3), 1201, 2010.

37. ZHANG C., GAO X.P., WANG L.Y., CHEN X.J. Modelling the role of epiphyton and water level for submerged macrophyte development with a modified submerged aquatic vegetation model in a shallow reservoir in China. Ecol. Eng. 81, 123, 2015.

38. ASMUS R., ASMUS H., VAN DUREN L. Introduction: Hydrodynamic control of aquatic ecosystem processes-
How does water movement affect different levels of organisation?. Estuar Coast Shelf S. 75, 279, 2007.

39. SU W.H, ZHANG G.F., ZHANG Y.S., XIAO H., XIA F. Photosynthetic characteristics of five submerged macrophytes. Acta Hydrobiologica Sinica. 4, 391, 2004 [In Chinese].

40. BINZER T., SAND-JENSEN K., MIDDELBOE A.L. Community photosynthesis of aquatic macrophytes. Limnol. Oceanogr. 51 (6), 2722, 2006.

41. BU H.Y., GE W.J., ZHOU X.H., QI W., LIU K., XU D.H., WANG X.J., DU G.Z. The effect of light and seed mass on seed germination of common herbaceous species from the eastern Qinghai-Tibet Plateau. Plant Spec. Biol. 32 (4), 263, 2017.

42. LARSON J.E., FUNK J.L. Regeneration: an overlooked aspect of trait-based plant community assembly models. J. Ecol. 104 (5), 1284, 2016.

43. MOORE K.A., ORTH R.J., NOWAK J.F. Environmental regulation of seed germination in Zostera marina L. (eelgrass) in Chesapeake Bay effects of light, oxygen and sediment burial. Aquat. Bot. 45, 79, 1993.

44. BRENCHLEY J.L., PROBERT R.J. Seed germination responses to some environmental factors in the seagrass Zostera capricorni from eastern Australia. Aquat. Bot. 62, 177, 1998.

45. CABAÇO S., SANTOS R. Reproduction of the eelgrass Zostera marina at the species southern distributional limit in the Eastern Atlantic. Mar. Ecol. 31 (2), 300, 2010.

46. HU J.J., LUO C.C., TURKINGTON R., ZHOU Z.K. Effects of herbivores and litter on Lithocarpus hancei seed germination and seedling survival in the understorey of a high diversity forest in SW China. Plant Ecol. 217, 1429, 2016.

47. SANTOS J.C., ARAUJO N.A.V., VENÂNCIO H., ANDRADE J.F., ALVES-SILVA E., ALMEIDA W.R., CARMO-OLIVEIRA R. How detrimental are seed galls to their hosts? Plant performance, germination, developmental instability and tolerance to herbivory in Inga laurina, a leguminous tree. Plant Biology. 18, 962, 2016.

48. VAN ZUIDAM B.G., PEETERS E.T. Wave forces limit the establishment of submerged macrophytes in large shallow lakes. Limnol. Oceanogr. 60, 1536, 2015.

49. FRANKLIN P., DUNBAR M., WHITEHEAD P. Flow controls on lowland river macrophytes: a review. Sci. Total Environ. 400, 369, 2008.

50. DORENBOSCH M., BAKKER E.S. Herbivory in omnivorous fishes: effect of plant secondary metabolites and prey stoichiometry. Freshwater Biol. 56, 1783, 2011.

51. KAPUSCINSKI K.L., FARRELL J.M., STEHMAN S.V., BOYER G.L., FERNANDO D.D., TEECE M.A., TSCHAPLINSKI T.J. Selective herbivory by an invasive cyprinid, the rudd Scardinius erythrophthalmus. Freshwater Biol. 59, 2315, 2014.

52. SUN J., WANG L., MA L., MIN F.L., HUANG T., ZHANG Y., WU Z.B., HE F. Factors affecting palatability of four submerged macrophytes for grass carp Ctenopharyngodon idella. Environ. Sci. Pollut. R. 1, 2017.

53. KLOSKOWSKI J. Impact of common carp Cyprinus carpio on aquatic communities: direct trophic effects versus habitat deterioration. Fund. Appl. Limnol. 178 (3), 245, 2011.

54. VAN DER WAL J.E.M., DORENBOSCH M., IMMERS A.K., FORTEZA C.V., GEURTS J.J.M., PEETERS E.T.H.M., KOESE B., BAKKER E.S. Invasive crayfish threaten the development of submerged macrophytes in lake restoration. Plos One. 8 (10), e78579, 2013. 
